\title{
The Effect Of Blended Learning Approach On Fifth Grade Students' Academic Achievement In My Beautiful Language Textbook And The Development Of Their Verbal Creative Thinking In Saudi Arabia
}

Feras Mohammed Al-Madani, Northern Border University, Saudi Arabia

\begin{abstract}
This study aims at investigating the effect of Blended Learning approach compared to the traditional learning approach on fifth grade students' achievement in My Beautiful Language Textbook and the development of their verbal creative thinking. The study consisted of 49 students among which 25 are males in the Experimental Group and 24 females in the Control Group. The study found a statistical significant difference $(\alpha \leq 0.05)$ between the mean scores of the two study groups in achievement posttest and verbal creative thinking post application test. The experiment group which was taught using the blended approach of learning outperformed the Control Group in both tests. Thus, learning My Beautiful Language Textbook using the blended approach is more effective than the traditional method in terms of achievement and the development of verbal creative thinking skills. In light of this, the study recommends the adoption of blended approach in learning My Beautiful Language Textbook, the curriculum computerization, holding series of training courses, and workshops for teachers in school districts on how to effectively implement the blended approach.
\end{abstract}

Keywords: Blended Learning; Academic Achievement; My Beautiful Language Textbook; Verbal Creative Thinking; Fifth Grade.

\section{INTRODUCTION}

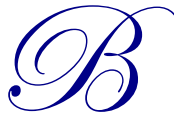

lended Learning is a modern strategy in the realm of education. It is gradually replacing e-learning in most of the educational institutions. The Blended Learning is an alternative for e-learning. In blended learning, it is easy for the teacher to blend traditional classroom with computer based virtual classroom. To Milheim (2006), Blended Learning combines traditional learning with e-learning, while Poon (2013) opines that Blended Learning comingles teachers with students, and audio visual illustration or internet to improve the educational process.

Blended Learning is a form of direct and indirect learning. Usually, on one hand, it is a direct learning with the use of internet and intranet; on the other hand, it is an indirect learning when it occurs in the traditional classroom (Krause, 2007).

Blended Learning is a kind of e-learning which employs a range of tools and educational aids in order to create an interactive learning environment synchronously or asynchronously, serves both student and teacher, enhances the learning process for offering programs and courses electronically via different multimedia communication tools including e-mail, instant messaging, mailing lists and forums to overcome the traditional 
problems of environment where the teacher has limited opportunities to observe students and correct their mistakes during learning process (Ibrahim, 2011).

The Blended Learning environment is a learning environment that combines electronic and traditional learning. It enables student-teacher interaction, or student-content interaction, or student-student interaction through direct dialogue or discussion in order to overcome the obstacles of electronic and traditional learning environments and develops students' knowledge and skills effectively. The Blended Learning environment overcomes the social isolation imposed by the e-learning, by mixing it up with traditional education inside the classroom. In the context of blended learning, students are the main focus in order to meet their actual needs through studying educational content which is far away from the routine traditional environment via direct meeting and online communication (Ziyabaat, 2013).

The concept of Blended Learning which stems as a real information technology solution integrates elearning with traditional learning in a single model to take advantage of both learning styles in achieving the desired educational goals.

\section{Problem Statement}

The problem of this study emerges as a need to the diversification of the teaching methods especially in My Beautiful Language Textbook; a book recently written in Saudi Arabia that includes all branches of the Arabic language namely; (reading, grammar, dictation, speaking, and calligraphy). The book was written purposely to address the difficulties teachers face in the delivery of content of this textbook to the students which reflected negatively on their level of achievement. This requires the teachers to search for alternative teaching methods to help students learn. Blended Learning is a modern learning method that blends the traditional learning and learning via computer and internet to increase students' achievement.

\section{Significance of the Study}

Blended Learning will display the positive aspects of traditional and e-learning to overcome the disadvantages of each learning approach. This study will provide those in charge of teaching the Arabic language an insight to inculcate Blended Learning in teaching Arabic language. The results of this study will provide the curriculum designers specific guidelines to plan when developing it.

\section{Research Questions}

1. What is the effect of using Blended Learning on fifth graders' achievement in My Beautiful Language Textbook?

2. What is the effect of using Blended Learning on fifth graders' development of verbal creative thinking skills?

3. Is there a statistical significant difference at $(\alpha \leq 0.05)$ in the fifth graders' achievement of My Beautiful Language Textbook in accordance with the learning method?

4. Is there a statistical significant difference at $(\alpha \leq 0.05)$ in students' verbal creative thinking with regards to the learning method?

\section{Research Hypotheses}

$\mathbf{H}_{1}$ : There is no statistical significant difference at the probability level of $(\alpha \leq 0.05)$ between the average scores of students in the control and Experimental Group in the post achievement test according to learning approach.

$\mathbf{H}_{2}$ : There is no statistical significant difference at the probability level of $(\alpha \leq 0.05)$ between the students' verbal creative thinking skills in the control and experimental cohort in the post test in accordance with the learning approach. 


\section{Method}

Experimental Research Design was used in this study to investigate the effect of the Blended Learning approach on the fifth graders' achievement in My Beautiful Language Textbook. The sample of this study consisted of two cohorts: namely, experimental cohort who learnt through Blended Learning approach and Control Group which learnt via traditional method.

\section{Sample}

The study sample consisted of 49 students from the fifth grade who were distributed into Experimental Group (25) students who learnt using the Blended Learning approach and the Control Group (24) students who learnt using the traditional learning approach.

\section{Instruments}

The research instrument used is of two folds. The first instrument was the achievement test for My Beautiful Language Textbook to measure students' achievement of the concepts and language skills in the unit six, book two of My Beautiful Language Textbook. The second instrument was a verbal creative thinking using Torrance test which is an appropriate measure that has been empirically tested in the Arab environment locally and the Arab literature educationally starting from the fourth grade through the University Level. 


\section{Research Design}

Figure 1. The effect of blending learning approach and the development of verbal creative thinking in Saudi Arabia

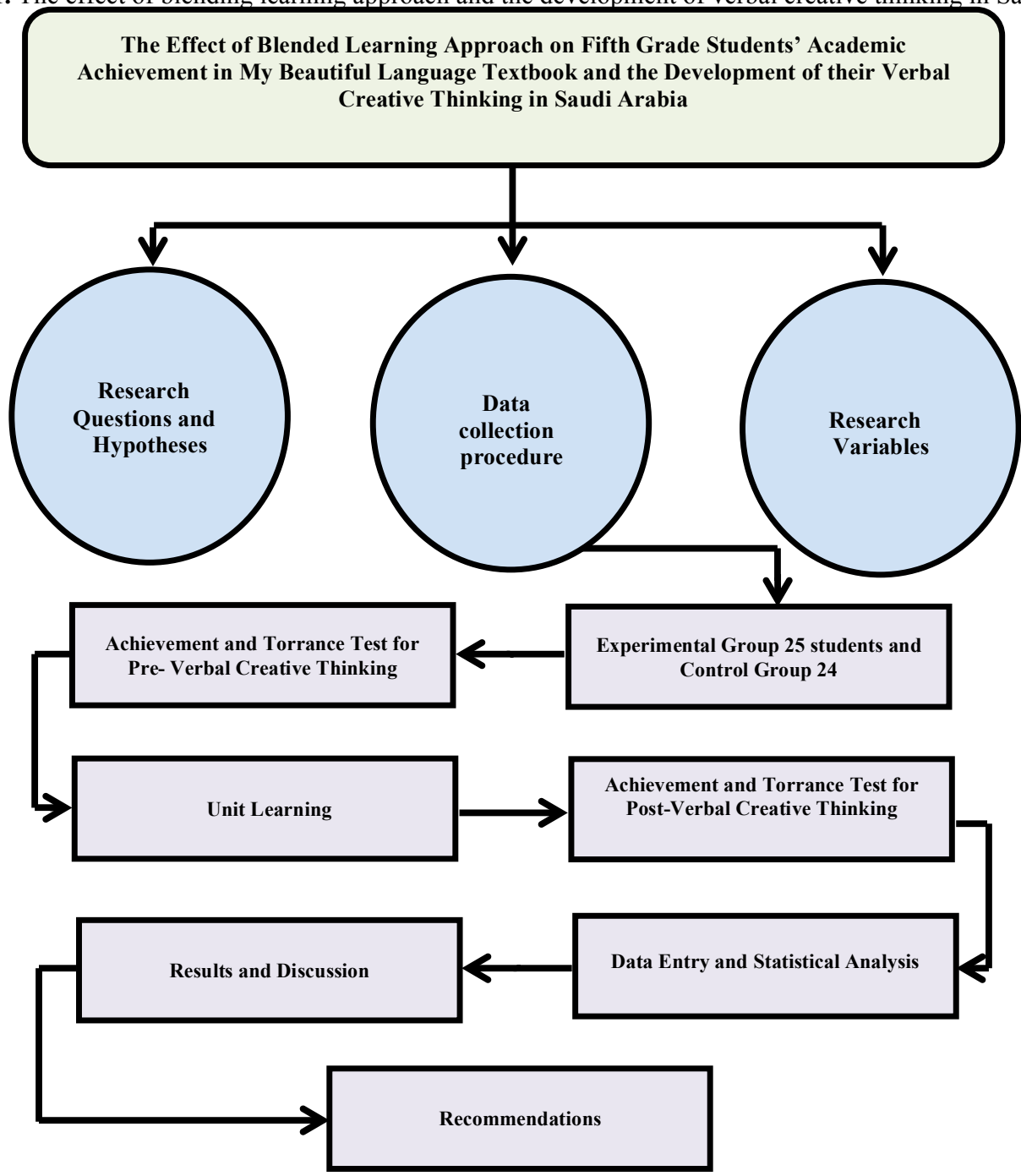

\section{RESULT AND DISCUSSION}

The First Hypothesis

Table 1. Mean scores and Standard Deviations for the two groups' pre and post achievement tests

\begin{tabular}{lc|cc|cc}
\hline \multirow{2}{*}{ Group } & \multirow{2}{*}{ Size } & \multicolumn{3}{c}{ Pretest } & \multicolumn{3}{c}{ Posttest } \\
\cline { 3 - 6 } & & Mean & Std & Mean & Std \\
\hline Experimental Group & 25 & 18.56 & 7.43 & 28.2 & 8.42 \\
Control Group & 24 & 17.83 & 6.16 & 24.83 & 6.65 \\
\hline
\end{tabular}

Table 1 shows that the average scores of students in the Control Group in the pre-achievement test are $(\mathrm{M}=$ 17.83) and the posttest are $(\mathrm{M}=24.83)$ with a difference of (7) in favor of the post achievement test. The same table shows that, the average scores of students in the Experimental Group in pre achievement test are $(\mathrm{M}=18.56)$ and the posttest are $(\mathrm{M}=28.2)$ with a difference of $(9.64)$ in favor of the posttest which indicate that, the Experimental 
Group is better than Control Group. In order to test the significance of this difference, the results of Analysis of Covariance (ANCOVA) were as shown in Table 2.

Table 2. ANCOVA Results for the two groups 'post achievement test

\begin{tabular}{lccccc}
\hline \multicolumn{1}{c}{ Source } & Sum of Squares & df & Mean Square & F & Sig. \\
\hline Pretest & 2677.641 & 1 & 2677.641 & 884.107 & 0.000 \\
Learning method & 83.464 & 1 & 83.464 & 27.558 & 0.000 \\
Error & 139.317 & 46 & 3.029 & & \\
Corrected Total & 36188.000 & 49 & & & \\
\hline
\end{tabular}

Table 2 shows value of $\mathrm{F}$ statistics (27.55) and significance level $(0.000)$ which indicates statistical significant difference at $(\alpha \leq 0.05)$ between the students' mean scores in the post achievement test in favor of the students in Experimental Group who studied via blended learning. The null hypothesis indicates that the use of Blended Learning method increases the efficiency of achievement.

\section{The Second Hypothesis}

Table 3. Mean and Standard Deviations for the two groups' pre and post verbal creative thinking test scores

\begin{tabular}{lc|cc|cc}
\hline \multirow{2}{*}{ Group } & \multirow{2}{*}{ Size } & \multicolumn{2}{c|}{ Pretest } & \multicolumn{2}{c}{ Posttest } \\
\cline { 3 - 6 } & & Mean & Std & Mean & Std \\
\hline Experimental Group & 25 & 88.36 & 20.79 & 94.64 & 19.48 \\
Control Group & 24 & 91.16 & 21.70 & 92 & 21.35 \\
\hline
\end{tabular}

Table 3 shows that the average students' grade in the Experimental Group with regards to the pre verbal creative thinking test are $(M=88.36)$, its posttest is $(M=94.64)$ with a difference of $(M=6.28)$ in favor of the posttest, and that the average students' grades in the Control Group with regards to the pre verbal creative thinking test are $(M=91.16)$, its posttest is $(M=92)$ with a difference of $(M=0.84)$ in favor of the posttest meaning that the difference was in favor of the students in Experimental Group. In order to test the significance of this difference the results of ANCOVA was run as shown in Table 4.

Table 4. Results of ANCOVA for the two groups' post verbal creative thinking test

\begin{tabular}{lccccc}
\hline \multicolumn{1}{c}{ Source } & Sum of Squares & df & Mean Square & F & Sig. \\
\hline Pretest & 20940.35 & 1 & 20940.35 & 5686.21 & 0.000 \\
Learning method & 346.84 & 1 & 346.84 & 94.18 & 0.000 \\
Error & 169.40 & 46 & 3.68 & & \\
Corrected Total & 21195.10 & 48 & & & \\
\hline
\end{tabular}

Table 4 shows the value of $\mathrm{F}$ statistics (94.18), its significance level (0.000) which indicates a statistical significant difference $(\alpha \leq 0.05)$ between the students' mean scores in both groups in the post verbal creative thinking test in favor of the students in Experimental Group who studied using blended learning. The results obtainable lead to the rejection of null hypothesis and clearly indicated that Blended Learning increases the learning efficiency of the students 'verbal creative thinking skills.

\section{Fluency Skill}

Table 5. Mean and Standard Deviations for the two groups' fluency skill in pre and post verbal creative thinking test scores

\begin{tabular}{|c|c|c|c|c|c|}
\hline \multirow{2}{*}{ Group } & \multirow{2}{*}{ Size } & \multicolumn{2}{|c|}{ Pretest } & \multicolumn{2}{|c|}{ Posttest } \\
\hline & & Mean & Std & Mean & Std \\
\hline Experimental Group & 25 & 42.04 & 4.96 & 43.68 & 4.40 \\
\hline Control Group & 24 & 42.79 & 5.26 & 43.04 & 5.27 \\
\hline
\end{tabular}

Table 5 shows that the average students' scores in the Experimental Group with regards to the fluency skill in the pre creative thinking test is $(M=42.04)$, post creative thinking test is $(M=43.68)$ with a difference of $(M=$ 1.64) in favor of posttest application, and that the average students' scores in the control with regards to posttest is $(\mathrm{M}=42.79)$, its post test is $(\mathrm{M}=43.04)$ with a difference of $(\mathrm{M}=0.25)$ in favor of the posttest scores, which indicate 
that the difference was in favor of the Experimental Group students. The results of ANCOVA show the significance of this difference as in Table 6.

Table 6. Results of ANCOVA for students' grades in two groups in fluency skill in the post creative thinking test

\begin{tabular}{lccccc}
\hline \multicolumn{1}{c}{ Source } & Sum of Squares & df & Mean Square & F & Sig. \\
\hline Pretest & 1185.71 & 1 & 1185.71 & 1277.98 & 0.000 \\
Learning method & 21.69 & 1 & 21.69 & 23.38 & 0.000 \\
Error & 42.67 & 46 & 0.92 & & \\
Corrected Total & 1233.38 & 48 & & & \\
\hline
\end{tabular}

Table 6 shows the value of F statistics (23.381) for fluency skill, the level of significance $(0.000)$ which indicates the statistical significant difference at $(\alpha \leq 0.05)$ between the students' mean scores in the two groups with regards to fluency skill in the post creative thinking test in favor of students in the Experimental Group who learnt using Blended Learning method. These results lead to the rejection of null hypothesis meaning that the Blended Learning increases efficiency in the development of fluency skill.

\section{Flexibility Skill}

Table 7. Means and Standard deviations for both two groups in the flexibility skill in pre and post creative thinking tests

\begin{tabular}{lc|cc|cc}
\hline \multirow{2}{*}{ Group } & \multirow{2}{*}{ Size } & \multicolumn{2}{c|}{ Pretest } & \multicolumn{2}{c}{ Posttest } \\
\cline { 3 - 6 } & & Mean & Std & Mean & Std \\
\hline Experimental Group & 25 & 22.84 & 7.98 & 25.52 & 7.44 \\
Control Group & 24 & 23.916 & 8.31 & 24.16 & 8.25 \\
\hline
\end{tabular}

Table 7 shows the average students' grades in the Experimental Group with regards to the flexibility skill in the pre creative thinking test $(M=22.84)$, their average scores in post flexibility skill test $(M=25.52)$ with a difference of $(M=2.68)$ in the posttest, and the average students' scores in the Control Group with $(M=23.91)$, the average scores in the posttest $(\mathrm{M}=24.16)$ with a difference of $(\mathrm{M}=0.25)$ in the posttest which indicates that the difference in the flexibility skill in post and pre creative thinking tests was in favor of students in the Experimental Group. The significance of this difference is as shown in ANCOVA Table 8.

Table 8. Results of ANCOVA for students' grades in both groups in the flexibility skill in post creative thinking test

\begin{tabular}{lccccc}
\hline \multicolumn{1}{c}{ Source } & Sum of Squares & df & Mean Square & F & Sig. \\
\hline Pretest & 3023.16 & 1 & 3023.16 & 3620.19 & 0.000 \\
Learning method & 69.40 & 1 & 69.40 & 83.10 & 0.000 \\
Error & 38.414 & 46 & 0.83 & & \\
Corrected Total & 3084.00 & 48 & & & \\
\hline
\end{tabular}

Table 8 shows the value of $F$ statistics for the flexibility skill (83.10) and the level of significance (0.000) which indicates the statistical significant difference $(\alpha \leq 0.05)$ between the mean scores of the two groups in flexibility skill in post creative thinking test in favor of students in the Experimental Group who learned using blended learning. This result leads to the rejection of null hypothesis meaning that Blended Learning increases efficiency in the development of flexibility skill.

\section{Originality Skill}

Table 9. Mean and Standard Deviations of two groups in the originality skill in both pre and post creative thinking test

\begin{tabular}{lc|cc|cc}
\multicolumn{1}{c}{ Group } & \multirow{2}{*}{ Size } & \multicolumn{2}{c|}{ Pretest } & \multicolumn{2}{c}{ Posttest } \\
\cline { 3 - 6 } & & Mean & S.d & Mean & Std \\
\hline Experimental Group & 25 & 23.48 & 8.24 & 25.44 & 8.15 \\
Control Group & 24 & 24.45 & 8.54 & 24.79 & 8.20 \\
\hline
\end{tabular}

Table 9 shows the average students' grades in the Experimental Group in originality skill in the pre creative thinking test $(M=23: 48)$, the average scores in the posttest $(M=25.44)$ with a difference of $(M=1.96)$ in 
favor of the posttest, and the average students' scores in the Control Group in the pretest $(\mathrm{M}=24.45)$ the average scores in the posttest $(\mathrm{M}=24.79)$ with a difference of $(\mathrm{M}=0.34)$ for posttest meaning that the difference in originality skill between the post and pre creative thinking tests is in favor of students in the Experimental Group. The results of the significance of this difference are as shown in Table (10) of ANCOVA.

Table 10. Results of ANCOVA for both two students' grades in the originality skill in post creative thinking test

\begin{tabular}{lccccc}
\hline \multicolumn{1}{c}{ Source } & Sum of Squares & df & Mean Square & F & Sig. \\
\hline Pretest & 3306.36 & 1 & 3306.36 & 3620.19 & 0.000 \\
Learning method & 31.25 & 1 & 31.25 & 83.10 & 0.000 \\
Error & 53.75 & 46 & 1.16 & & \\
Corrected Total & 3365.26 & 48 & & & \\
\hline
\end{tabular}

Table 10 shows the value of $\mathrm{F}$ calculated for the originality skill (26.74) and the level of significance $(0.000)$, which indicates a statistical significant difference $(\alpha \leq 0.05)$ between the mean scores of the two groups in the originality post creative thinking test. These results indicate the rejection of the null hypothesis meaning that Blended Learning increases efficiency in the development of the originality skill.

\section{CONCLUSION}

The researcher concludes from the above illustrated results that Blended Learning improves students' performance and achievement in My Beautiful Language Textbook because it enhances their level of verbal creative thinking.

\section{RECOMMENDATIONS}

This study recommends:

1. Adopting Blended Learning approach for teaching and learning Arabic language.

2. Holding training courses and workshops for the teachers in the education departments in school districts on how to implement blended and e-learning.

3. Providing a conducive environment in schools for the application of this type of learning.

4. Working on curriculum computerization, burning it into CD-ROMs, and distributing it to the students with the textbook at the beginning of the school academic year.

5. Encouraging teachers to use Blended Learning and other teaching methods in the educational process.

\section{AUTHOR INFORMATION}

Feras Mohammed Al-Madani, PhD., an assistant professor at the Faculty of Education and Arts and Vice Dean of Scientific Research, Northern Border University, Saudi Arabia; research areas: curriculum and instruction, Arabic language, professional development, teacher education, human rights, Counter-Terrorism and Counter-financial and administrative corruption. E-mail: fmabm@hotmail.com.

\section{REFERENCES}

Bani Hamad, A. A. (2011). The effect of Blended Learning style of third graders' achievement and motivation to learn Arabic language, Studies in Educational Sciences, Vol. 38, 1.

Bello-Haas, V., Proctor, P., P.T., \&Scudds, Rhonda, PT,PhD., M.Sc. (2013). Comparison of knowledge and knowledge application confidence in physical therapist students completing a traditional versus blended learning professional issues course. Journal of Physical Therapy Education, 27(1), 10-19. Retrieved from http://search.proquest.com/docview/1282107773?accountid=142908

Freeman, W., \& Tremblay, T. (2013). Design considerations for supporting the reluctant adoption of blended learning. Journal of Online Learning and Teaching, 9(1), 80. Retrieved from $\mathrm{http}: / /$ search.proquest.com/docview/1500389476? accountid=142908 
Gleason, J. (2013). Dilemmas of blended language learning: Learner and teacher experiences. CALICO Journal, 30(3), 323-n/a. doi:http://dx.doi.org/10.11139/cj.30.3.323-341

Haddad, R. (2007). The effect of Blended Learning on students' achievement and science skills acquisition, Basic Education, Jordan.

Ibrahim, H. M. M. (2011). The effect of different learning environment, training style in developing skills and bibliographic productivity of students in the library, information, and Technology Education. Faculty of Education Magazine, Al-Azhar University, Vol. 145, 2.

Korkmaz,O\&Karakus,U.(2009) :The Impact of Blended Learning Modelstudent attitudes towards Geography course and therecritical thinking, dispositions and levels.Journal of Educational Technology.

Krause,K.(2007):Griffith University Blended Learning strategy,Document number2008/0016252.

Lotrecchiano, G. R., Mcdonald, P. L., Lyons, L., Long, T., \&Zajicek-farber, M. (2013). Blended learning: Strengths, challenges, and lessons learned in an interprofessional training program. Maternal and Child Health Journal, 17(9), 1725-34. doi:http://dx.doi.org/10.1007/s10995-012-1175-8

Manguire,K.(2005):Professional development in blended e-learning environment for middle school mathematics teachers.(M.A.dissertation), Canada:Yniversity of Toronto.

Milheim,W.D.(2006):Strategies for the Design and Delivery of Blended Learning Courses. Journal of Educational Techology.18(3),99-105.

Omari, O. (2012). The effectiveness of a computerized educational program in developing seventh graders' creative thinking in Jordan. Damascus University Journal, Volume 28, No.1.

Poon, J. (2013). An examination of a blended learning approach in the teaching of economics to property and construction students. Property Management, 31(1), 39-54. doi:http://dx.doi.org/10.1108/02637471311295405

Poon, J. (2013). Blended learning: An institutional approach for enhancing students' learning experiences. Journal of Online Learning and Teaching, 9(2), 271. Retrieved from $\mathrm{http}: / /$ search.proquest.com/docview/1500421423? accountid=142908

Qarariha, A. O. (2013). The effectiveness of Blended Learning on teaching science among ninth graders and the development of thinking skills. Journal of Educational and Psychological Sciences, Volume 14, No. 2.

Saqeer, A. M. A. I. (2011). The effectiveness of Blended Learning in developing geographical concept and motivating junior school students toward it. Master' degree in Education, Ain Shams University.

Shaheen, S. A. (2008). The effectiveness of Blended Learning on achievement, development of primary students' ability in science, and their attitudes toward it. Faculty of Education, Department of Curriculum and Instruction, Technology Education, Tanta University.

Sriwongkol,T (2007):Development of AAA Model for Blended Learning based on the philosophy of sufficiency Economy, King Mongkuts Institute of Technology, North Bangkok.

Taha, A. (2012). The effectiveness of using Blended Learning in cognitive knowledge and developing university skills among students of the Faculty of Education. University of Kafr El-Sheikh, Journal of Association of Arab Universities.

Taylor, R.(2007):A blended online instructional approach to physical education instruction: A combination to enhance student cognitive and physical ability Retrieved from a Pro Quest Digital Dissertations.

Thang, S. M., Mustaffa, R., Wong, F. F., Noor, N. M., Mahmud, N., Latif, H., \& Aziz, M. S. A. (2013). A quantitative inquiry into the effects of blended learning on english language learning: The case of malaysian undergraduates. International Education Studies, 6(6), 1-7. Retrieved from http://search.proquest.com/docview/1448007753?accountid=142908

Vayghan, R(2003):Exploring hoe Blended Learning could support faculty development in higher education, The Graduatdivition of educational research.Degree of doctor of philosophy, Galgary,Alberta.

Zarnoqi, N. (2007). The effect of computer on developing female students' innovative thinking and academic achievement in Physics. Jeddah, Saudi Arabia. 